\title{
Analysis and Evaluation of the Ecological Restoration of the City with an Emphasis on Urban Metabolism
}

\author{
Ahmadreza Lotfi ${ }^{1}$, Seyed Abdolhadi Daneshpour ${ }^{2 *}$ \\ ${ }^{1}$ University of Tehran, Tehran, Iran \\ ${ }^{2}$ Urban Design and Planning Department, Iran University of Science and Technology, Tehran, Iran \\ Email: *Daneshpour@iust.ac.ir
}

Received 25 April 2016; accepted 24 May 2016; published 27 May 2016

Copyright (C) 2016 by authors and Scientific Research Publishing Inc.

This work is licensed under the Creative Commons Attribution International License (CC BY).

http://creativecommons.org/licenses/by/4.0/

(c) (i)

Open Access

\begin{abstract}
It would not be far-fetched to say that people's lives depend on their environment and its quality. With growing urbanization of this dependence is growing increasingly urban environment. Urbanization not only balances economic and social development in the cities but also stirs the regional ecological imbalances and the natural areas. In addition to these problems, there is disruption of water, air, soil and environment built on imbalances between urban areas and the lack of social vitality and frustration. All cities, especially metropolitan with developing economies face to uncertainty in terms of health, environment and quality of life. This article utilizes the ecological and environmental issues and integrates it with urban metabolism approach to the study's revival of urban ecology, something that results in enhanced quality of life for citizens. This research is the theoretical and analytical method. In the research process of this study, related domestic and foreign literature subsequently of traditional and electronic library resources, books and articles published in journals have been used. According to the type of research in this study, descriptive analysis was performed. Based on findings of this study, urban ecology is a tool to control and guide of urban growth and activities in a way to improve quality of urban environment. Applying urban ecology in designing cities has provided opportunities to create practical ecological systems. By using them, natural process, human activities and urban environment could be combined. Moreover, urban metabolism as an indicator of urban sustainability and a part of urban ecology includes two main related and non-contra-dictory approaches of odum and MFA. Due to difficulties which modern cities face to, benefiting and applying these approaches seem vital.
\end{abstract}

\section{Keywords}

Urban, Sustainable Development, Ecological Urbanism, Urban Metabolism

\footnotetext{
${ }^{*}$ Corresponding author.
}

How to cite this paper: Lotfi, A. and Daneshpour, S.A. (2016) Analysis and Evaluation of the Ecological Restoration of the City with an Emphasis on Urban Metabolism. Open Journal of Ecology, 6, 377-386. 


\section{Introduction}

In this age of ecological attitude, one of the most important issues in the world in sustainable development and land-use planning, especially in a city, is human population growth [1] [2]. Urban environment faces to urban population growth and natural ecosystem replacement. So that it is predicted that by 2050, 66 percent of the world's population will live in cities [3]. With the growing urban population, large cities are facing numerous problems such as expensive ground that play an important role in the growth of the city, land-use changes and restrictions on the development of green spaces and even replacing them with other kinds of land uses such as residential or commercial inner city and industrial users have been on the fringes of cities.

The importance of water as a common resource is considered in many cities [4]. Nature is rapidly declining, and this will gradually lead to a shortage of fresh water. While freshwater resources are limited, water shortages are due to political competitions, the technological and financial barriers, and limited access to water leads [5]. It promotes urban agriculture programs, as a part of an integrated approach to water it. Also due to agricultural resources, livestock, aquaculture, high consumption and high demand for energy-intensive goods, food security and self-sufficiency have become a pervasive problem in many areas. Also, due to population growth and higher standards expected by 2050, global demand for food will increase to 70\% - 90\% [6]. With urbanization, pollution and effects of climate change, fertile agricultural areas are declining. Water is running out. Three-quarters of fish have been exploited. It is expected that in 2050 it will destroy most fish [7]. Rainforests to preserve ecosystems and carbon sinks are very important, for food production and supply of fossil fuels are now destroyed and are being destroyed.

Estimation showed that 850 million people would live with starvation while others had to change their lives and pass up goods and essential services such as health care and education [6] [8].

All the problems and complexities mentioned in urban ecology cause a sense of the need to consider new solutions such as ecological solutions with the metabolic approach as soon as possible, and with such an approach can reduce the damage to the city.

\section{The Purpose of the Study}

- Strict attention to the needs of future generations and design approaches metabolism (cycles), and energy production.

- Reconstructing urban ecology with an emphasis on urban metabolism.

\subsection{Eco-City}

The concept of ecological city was first proposed in 1971 by the United Nations. "Richard register" was one of the first writers to define the term Eco-City (Eco-City) in the book "Eco-City of Berkeley: building cities for salubrious future” in 1987 have been helpful [9] [10], so a precise definition of what could be ecological? Register defines ecological city (Figure 1 and Figure 2).

"Urban Eco-city is due to environmental impacts it is designed. The people are still concerned to minimize the energy needed for food, water, and waste heats output, air pollution, carbon dioxide, methane and water pollution has are. "And then states that" sustainable city itself through the natural environment surrounding the minimum required to feed and benefits of renewable energy (metabolism)" [9].

From this definition, it is clear that the aim of reducing the ecological footprint, produce the least amount of pollution, land use, land allocation efficient, open, use or manufacture of fertilizers, use of materials and technology to energy waste (Waste-to-Energy) is, therefore, influence the city or area of climate change is minimal. Three important elements ecological, people, economy and environment of the twenty-first century should be the new urban design language [11].

This model represents a model "green city." Optimum interaction of three factors: energy and materials, water and bio diversity, and urban planning and transportation, improve social and environmental sustainability of cities is the integrated model that identifies 15 basic principles pays [12].

Bahrain [13] ecological city knows that the following four characteristics:

- Minimum interference in the natural environment.

- The maximum diversity (in terms of land use and activities).

- If possible, a closed system.

- Optimum balance between population and resources. 


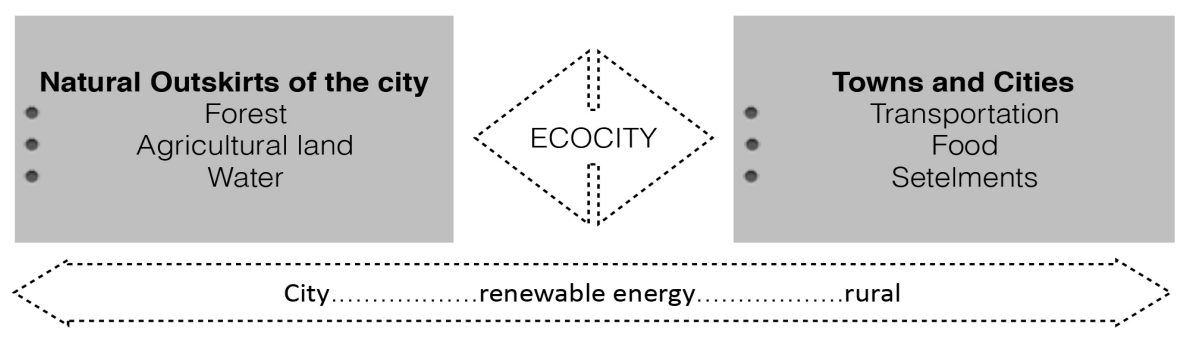

Figure 1. Index of ecological city.

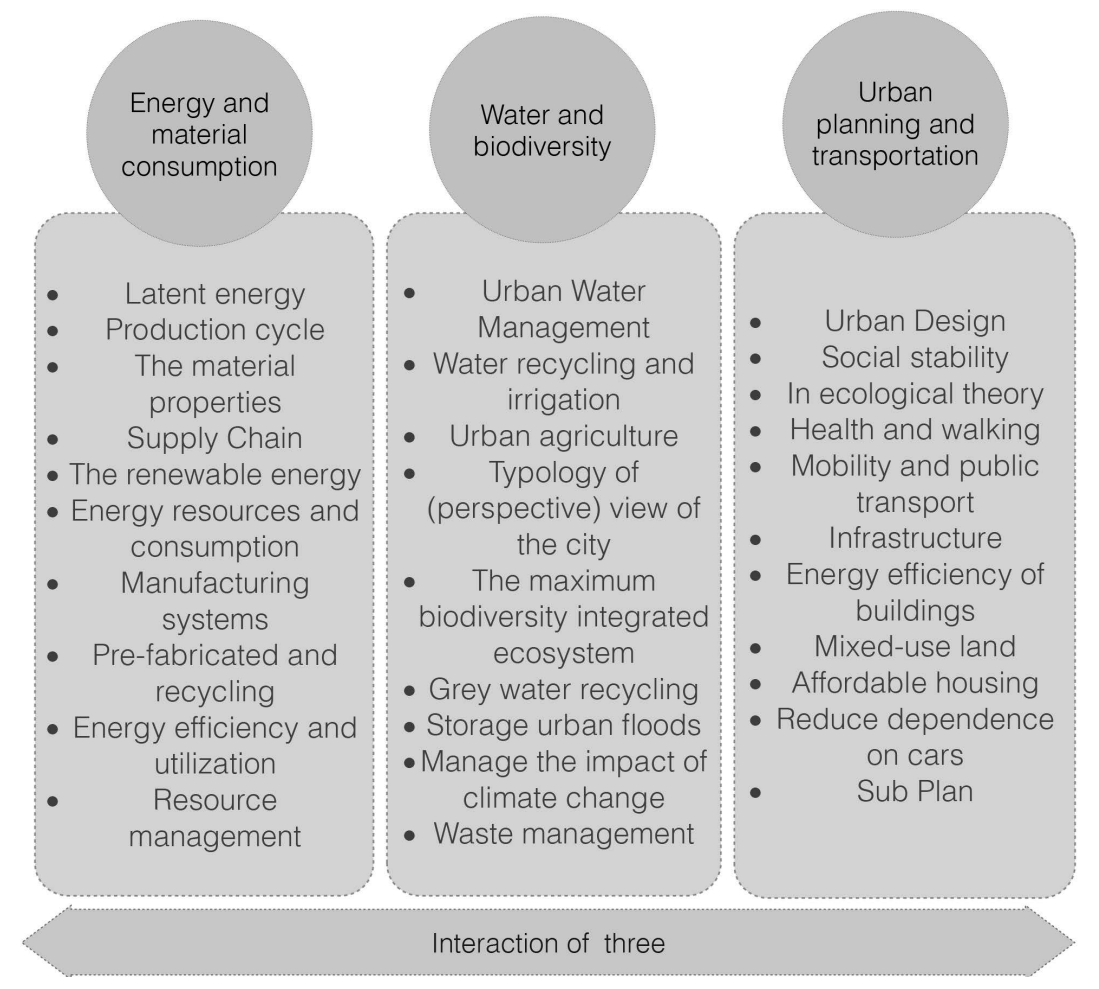

Figure 2. Ecological urbanism.

Philine Gaffron and Franz Skala book hallmarks of ecological these cities are shown in Figure 3 these features. Then Gaffron to five factors related to the development and ecological approaches to the city is: "context" and four urban developments, which include "urban structure," "transport," "metabolism" and "socio-economic aspects" have noted. Each component consists of funds that are used to organize and deliver operational goals (Figure 3).

In addition to the above, definitions should be noted that ecological or eco-city areas are holistic urban design solutions that improve the lives and health of the residents and communities through an integrated urban plan ning and management assistance and decrease the ecological benefits of renewable energy with the goal of zero waste, Zero-Emission pollution control, urban managers to come. Eco district natural asset by paying more ecological city of the future generations to preserve and strengthen an ecological civilization is at its core.

So today seek the deeper meaning of ecological civilization and harmonious life with nature finds it again. Ecological civilization was the result of deep thought and works in the industrial civilization and ecological city post-industrial civilization and ecological container and is a vehicle for [15].

The difference between the ecological city and existed cities are shown below (Figure 4).

\subsection{Ecological Network}

Ecological networks in the cities are often a series of green spaces and water basins (stains), green vectors, 


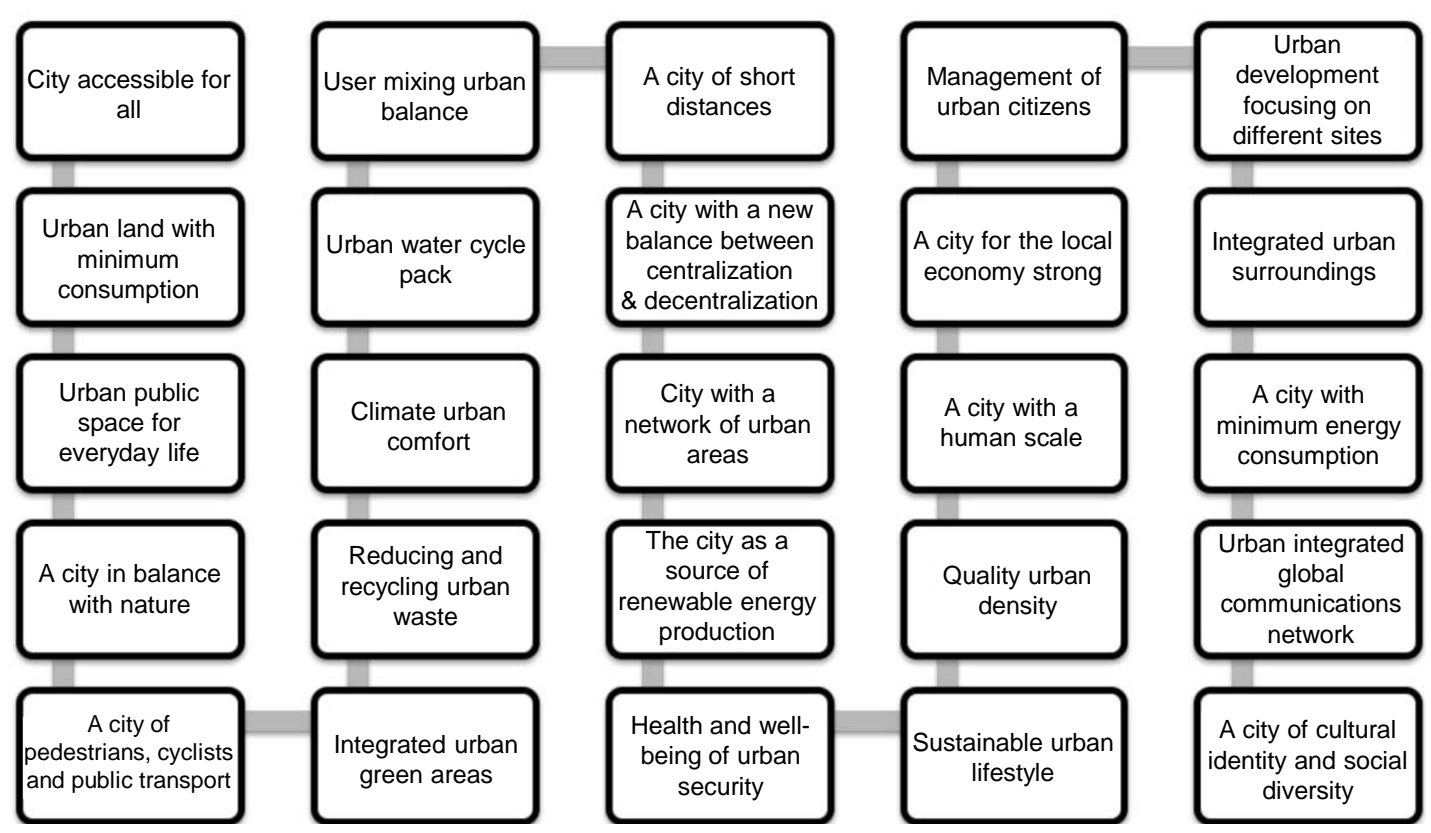

Figure 3. Hallmarks of an ecological city and the image of the landscape [14].

valleys and water channels (corridors). Larger stains and corridors, in terms of size, could cause the network to perform better in terms of environmental issues. Green path's margins vectors water currents cause stains connection to each other, and they play an important role in terms of environmental performance while maintaining the visual quality of their play [16].

Since the beginning of the 1990s, ecological networks play important roles in promoting processes of economic, social and ecological values of urban open spaces. The idea of ecological networks in Europe and in the United States in the early twentieth century and the green paths to connect the green or urban natural areas and forest systems have been performed [17].

Protection and development of green space and paths, urban and natural parks are ecological solutions for the preservation of bio diversity within cities [18]. Since there are the close relationships between the scenery and landscapes with identity [19], permeability, flexibility and linkages between green regions of cities with expansion of infrastructures and the creation of ecological networks has positive effects on reducing the environmental problems and promotion of the environmental identity [20].

\subsection{Ecological Development}

Ecological development tries to comprehend the interaction between environment, economy, politics and socialcultural factors that are based on ecological principles and will enable people to be in harmony with nature and will help them to achieve sustainable development [9].

In this way of the development, cities and towns should be designed to promote health and quality of life of their inhabitants and ecosystems that depend on them remain. Development of ecological citizenship decisions, public administration, industry, efficient, ecological, needs and expectations of people, cultures and landscapes with linking and thus nature, agriculture and the built environment can be integrated with each other, healthy applications (Figure 5).

Different aspects of the ecological development include different aspects of human life, that they could be presented as follows (all concepts described in Figure 6).

1) Ecological security.

2) Ecological health.

3) Ecological Industrial Metabolism.

4) Ecoscape.

5) Ecological awareness. 


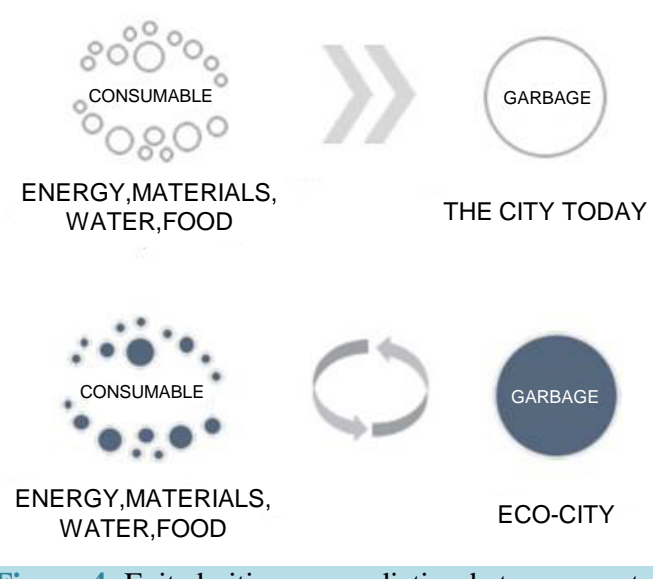

Figure 4. Exited cities are mediating between waste and recycling (graph above); the ecological city (ECO-CITY) is about the relationship between materials and minimizes waste (bottom graph).

\subsubsection{Ecological Development Characters}

Finally, the ecological development should have 3 following features:

1) Replicable (a model that is applicable in other regions).

2) Practical (in terms of sustainable economic).

3) Scalable (provided to other large-scale sites vary).

\subsubsection{Ecological Aspects of Urban Development}

By principles, it would be possible to categorize them in three general aspects:

- Establishing the "ecological” Urban environment (public transport and cycle recycling).

- Creating more efficient utilization of resources (land, water).

- Establishing livable cities (regeneration and urban programs against marginal settlements).

Each urban area should be seen as an ecosystem and therefore, construction should be done base on this perspective. It should be noted that these aspects should be used in an integrated form, so they can be led to ecological development. These aspects specified the strategies which are necessary to achieve the ecological city. However, it should be based on the site and scale of projects. At the beginning, access to some could be difficult but to achieve all these aspects is essential. In this way, they lead to establish a balance between urban growth and optimum application of natural resources.

\section{Principles of Urban Design with Ecological Development Approach}

Ecological designed and the concept of sustainability must be consistent. Consequently, the type of design must be consisted of the following principles [22] (Figure 7).

The design will be community-oriented, small-scale, local, appropriate technology, people-oriented, focused on users, context and culture, low cost, designed from the bottom up, inclusive seeking freedom and benefiting from the resources its own region [23].

\section{The Concept of Urban Metabolism}

The concept of urban metabolism was established by Wolman [24] that was the foundation for the development of sustainable cities and communities. Urban metabolism can be described as "the set of all technical and socioeconomic processes of growth, energy production and eliminate waste in the cities," defined [25]. In practice, the study of an urban metabolism is a "big picture" of quantification (quantity or become number) of inputs and outputs and stored energy, water, nutrients, and waste material in the city.

The concept of urban metabolism almost has been created by comparison with the metabolism of living organisms. Cities behave same as living beings in order to consuming materials and waste disposal. Cities convert raw materials, fuel and water into the built environment and send out biomass and waste [26]. However, cities 


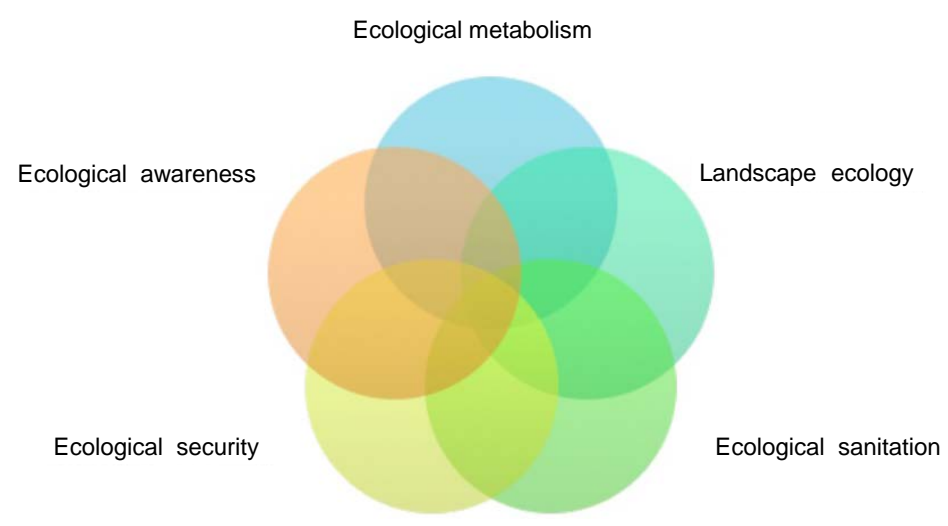

Figure 5. Ecological development [21].

\begin{tabular}{|c|c|}
\hline Ecological security & $\begin{array}{l}\text { Clean air, safe and reliable water supplies, food, } \\
\text { healthy work-life environment, urban services } \\
\text { and protection against natural disasters }\end{array}$ \\
\hline Ecological health & $\begin{array}{l}\text { Economic and efficient performance of } \\
\text { ecological engineering to refine the recycling of } \\
\text { human waste, gray water and all waste }\end{array}$ \\
\hline $\begin{array}{l}\text { Industrial ecological- } \\
\text { Metabolism }\end{array}$ & $\begin{array}{l}\text { Industrial Metabolism ecological environment } \\
\text { conservation by industrial transition, } \\
\text { emphasizing the use of re-building, the creation } \\
\text { of the life cycle of renewable energy, efficient } \\
\text { transportation responsiveness to human needs. }\end{array}$ \\
\hline Landscape ecology & $\begin{array}{l}\text { Order constructs the spaces left behind and Plaza } \\
\text { parks, streets and bridges of communication like } \\
\text { natural effects such as the topography of the land } \\
\text { and water routes to ensure that biodiversity and } \\
\text { the urban environment by paying more } \\
\text { accessible to all citizens to maximum and it has } \\
\text { to protect energy resources. Similarly, problems } \\
\text { such as car accidents, air pollution, the } \\
\text { destruction of the natural flow of water, } \\
\text { warming the earth by minimizing heat island }\end{array}$ \\
\hline Ecological awareness & $\begin{array}{l}\text { To help people to make their place in nature, } \\
\text { find their cultural identity. So they changed their } \\
\text { consumption behavior into their ability to protect } \\
\text { the urban ecosystem services to enhance quality } \\
\text { (Guattari, 2000) }\end{array}$ \\
\hline
\end{tabular}

Figure 6. The concept of ecological development.

are more complex than a living organism (city location a large number of organisms, humans, animals and plants).

So the notion that cities are like ecosystems, it is true. In fact, the models of natural ecosystem are objectives of the development of sustainable cities. Natural ecosystems generally are self-sufficient in terms of energy inputs or by permanent and preserved by Saprophagous (insects that break down organic matter and returned to the food chain.) How supplied each city has the same behavior will be more stable. However, contemporary compared to the natural ecosystem metabolism are more severe. The historical review shows that the movement maker of the 1970s, interest in urban metabolism almost faded in the 1980s. Then, after the re-emergence in the 1990s, the urban metabolism in the last 10 years grew by more than 30 papers have been produced in this 


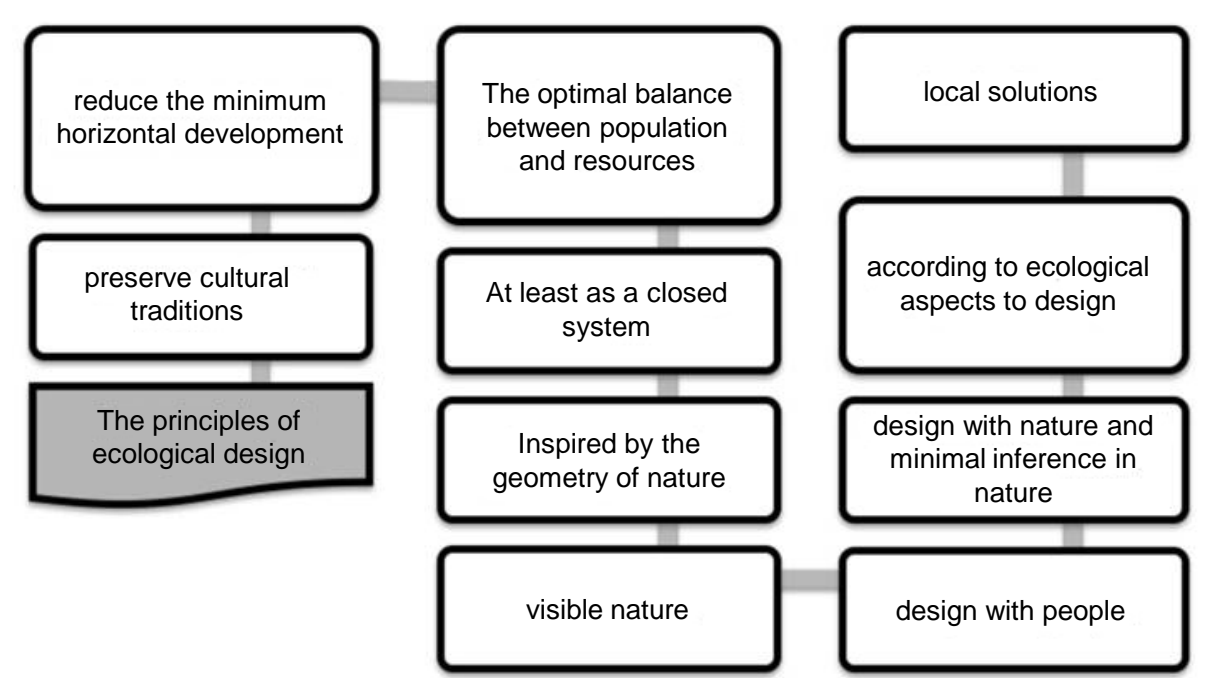

Figure 7. The principles of ecological design.

connection. In connection with the urban metabolism, two main schools have been set up. The first know metabolism equal to energy based on Odum's view point. The other includes the broader approach that defines the flow of water and nutrients in a city equal to the material's flow.

\section{Uses of Urban Metabolism (Application of Urban Metabolism)}

\subsection{Used as an Indicator of Stability (as an Indicator of Stability)}

Urbanmetabolismconsists of series of informationrelatedtoenergyefficiency, material cycling, Waste Management and urbaninfrastructuresystem. Generally, parameters of anurbanmetabolism are matchedwithindicators of sustainablemetropolitanpresentedby McLaren [27] They are scientifically valid (policy on energy and materials), representative, accountable, relevant to residents and city planners, based on data that are comparable across time, understandable and transparent [27].

\subsection{Data for Measuring Greenhouse-Gas Emissions}

By urban metabolism indicators, greenhouse-gas emissions (GHG) could be measured. This application is beneficial for cities aims to reduce these emissions. Carbon dioxide or methane and other gas are emitted directly from the cities, and they are inevitable. These gases usually have a broader range and include emissions (for example) or waste resulting from electricity generation in outside the city. What greenhouse-gas emissions within or outside urban boundaries to happen, it needs to be measured to calculate the consumption of materials and waste streams in urban metabolism.

In accordance with IPCC, a greenhouse-gas emission is calculated by multiplying the "level of activity" in the "release agent" for different sectors. For instance, greenhouse-gas emission from electricity generation is equal to multiplying the consumption level in the intensity of emissions from electricity generation at national, provincial or regional. Factors released from fuel used for heating, transport or industrial combustion is used well in the national report greenhouse gas emissions by fuel combustion characteristics are provided (Figure 8).

\subsection{Dynamic Mathematical Models for Policy Analysis}

While most researchers in the urban metabolism computing framework used as the basis for other researchers to develop mathematical models for the urban metabolism process. The mathematical model for research on a material, metal or nutrient in urban or regional metabolism was developed. For instance, SIMBOX [28] and STAN [29] is the significant ones. These sub-models, stocks and flows during metabolism and sometimes side by side with economic input-output model they give.

Although the models used to determine the reserve available materials and processes, it can also be used to predict the result of an intervention or policy changes for the future reconstruction of the city. These models are, 
in fact, to identify environmental solutions beyond just putting purifier approach at the end of the course (end of pipe).

\subsection{Urban Metabolism as a Tool for Sustainable Design}

Potential use of the concept of urban metabolism, urban design theme is relatively new. Perhaps the first serious effort to promote the study of design analysis Netzstadt book by Oswald and Baccini [30] is described. Fernandez and his students at MIT School of Architecture tried to redesign New Orleans based on the perspective of urban metabolism, moreover; civil students of the University of Toronto studied city metabolism to design infrastructure of a city.

In Netzstadt, Oswald and Baccini were trying to prove how they can be combined morphological and physiological tool for "a long process of rebuilding towns." They used this starting point that the center-periphery model of urban (downtown advanced, and the other regions are least developed) is outdated, and a new urban development is not sustainable.

Then they proposed four principles to redesign cities, including plasticity, stability, reconstruction and re-sponsibility. Five main factors of quality in cities include identification, diversity, flexibility and self-sufficiency degrees in resource that are considered in the design of urban metabolism. Four main activities of a city (nourishing and recovery, cleaning, settling and working, and moving and interacting) have been studied by Baccini and Brunner [31] based on four main urban metabolism sections (water, food (biomass), construction materials and energy). Lots of examples have demonstrated connection between morphological and physiological viewpoints.

The urban metabolism has been used in reconstructing of New Orleans by students from the University of Toronto. John Fernandez and his students at MIT used material flow analysis to offer more sensitive design to ecology for the city [32].

The University of Toronto also used students faced design challenges in local scale that integrates various infrastructures using the concept of neighborhood's metabolism [25] [33] [34]. Students benefited from the best design approaches for green buildings, sustainable transport and alternative energy systems in their work. By following the flow of water, energy, nutrients and materials in an urban system, a loop or ring could be

\begin{tabular}{|c|c|}
\hline Favorable unit & Components of urban metabolism \\
\hline GWh & Total power consumption \\
\hline $\begin{array}{l}\text { TJ for each type of } \\
\text { fuel }\end{array}$ & $\begin{array}{l}\text { Heating and industrial fuel consumption by fuel } \\
\text { type } \\
\text { For example, natural gas, fuel oil, coal, LPG } \\
\text { includes fuels that are used to generate heat and } \\
\text { electricity. }\end{array}$ \\
\hline $\begin{array}{l}\text { Million liters for } \\
\text { each type of fuel }\end{array}$ & $\begin{array}{l}\text { Total consumption of fuels used in transport } \\
\text { (gasoline, diesel and other) based on their sales } \\
\text { data }\end{array}$ \\
\hline Million liters & $\begin{array}{l}\text { The volume of aviation fuel at the airport based on } \\
\text { the placement of the city used }\end{array}$ \\
\hline Million liters & $\begin{array}{l}\text { The volume of fuel used in ships in the port (if } \\
\text { any) }\end{array}$ \\
\hline Tons and percent & $\begin{array}{l}\text { Tonnage (quantity in tonnes) and composition of } \\
\text { landfilled waste ( } \% \text { of the food, paper, wood, } \\
\text { textile and industrial) of all segments and our } \\
\text { percentage of burial }\end{array}$ \\
\hline Ton & Tonnage of waste burned (if any) \\
\hline Ton & $\begin{array}{l}\text { The accumulation of iron, cement and other } \\
\text { materials or chemical products in which the } \\
\text { production gas emissions }\end{array}$ \\
\hline
\end{tabular}

Figure 8. The components of urban metabolism that requires in greenhouse-gas emissions of a city or a community. 
designed that causes fewer resources consumption and less waste.

\section{Conclusions}

The city as a functioning ecosystem with a cycle of natural resources and human interaction has always been considered as the biggest centre of consumption. Urban development with the ecological approach is a tool to control and guide the development of activities and improve the quality of the urban environment. Benefiting ecological approaches to urban development provide opportunities to create practical systems could be used for integration natural process, urban environment and human activities.

Eco-city uses lands in the best possible way. In this type of city, the compromise with nature is happened by using materials based on the regression model (metabolism) rather than a linear model and also considering the efficiency of material. Energy, work, food, recreation and housing are used based on their relations with each other. In this city, people do shopping and go to work with limited distance from their home, and also this city has a good system of bike paths and sidewalks. By creating such a structure and inducing a sense of belonging to the environment in citizens' minds, they feel more responsible and could change identification of the place.

In the past decade, significant advances happened in terms of architecture and urban design regarding green and sustainable flows of energy and materials in scale of a building to community whether there were bigger obstacles toward architects, engineers and urban designers. Research topics related to the resource development in the countryside or in the city should be the main goal. Besides, urban designers need to engage more in fields such as energy and material flow. Urban metabolism design is faced with challenge of sustainable cities.

\section{References}

[1] Pickett, S.T., et al. (1992) The New Paradigm in Ecology: Implications for Conservation Biology above the Species Level. In: Fiedler, P.L. and Jain, J.A., Eds., Conservation Biology, Springer, Berlin, 1-23.

[2] Fiedler, P.L., et al. (1997) The Paradigm Shift in Ecology and Its Implications for Conservation. The Ecological Basis of Conservation. Chapman and Hall, New York, Springer, Berlin, 157.

[3] United-Nations (2014) World Urbanization Prospects. Volumes, New York.

[4] Seckler, D.W. (1998) World Water Demand and Supply, 1990 to 2025: Scenarios and Issues, IWMI.

[5] Falkenmark, M. and Lundqvist, J. (1998) Towards Water Security: Political Determination and Human Adaptation Crucial. Natural Resources Forum, 22, 37-51. http://dx.doi.org/10.1111/j.1477-8947.1998.tb00708.x

[6] Varma, S. (2008) Hunger Is Set to Grow as Global Food Stocks Fall. The Times of India, 1.

[7] UNEP (2007) GEO-4 (Global Environment Outlook 4) U. N. E. Programme. Nairobi, Kenya, 4.

[8] Jongman, R.H. and Pungetti, G. (2004) Ecological Networks and Greenways: Concept, Design, Implementation. Cambridge University Press, Cambridge. http://dx.doi.org/10.1017/CBO9780511606762

[9] Register, R. (1987) Ecocity Berkeley: Building Cities for a Healthy Future. North Atlantic Books, Berkeley.

[10] Cook, E. and Van Lier, H.N. (1994) Landscape Planning and Ecological Networks. Elsevier Science Ltd., USA.

[11] Sale, K. (2000) Dwellers in the Land: The Bioregional Vision. University of Georgia Press, Athens.

[12] Lehmann, S. (2006) Towards a Sustainable City Centre: Integrating Ecologically Sustainable Development (ESD) Principles into Urban Renewal. Journal of Green Building, 1, 83-104.

[13] Bahrain, H. (1999) Modernism, Post-Modernism and Then in Urban Planning. University of Tehran, Press Center, Tehran.

[14] Gaffron, P., et al. (2005) ECOCITY Book I “A Better Place to Live”. Hamburg, Utrecht, Vienna.

[15] Mostafavi, M. and Doherty, G. (2010) Ecological Urbanism. Harvard University Graduate School of Design, Lars Müller Publishers, Baden.

[16] Aminzadeh, B. and Ryamn, C. (2004) Principles and Strategies of This Post-Industrial Landscape. Honar-Ha-Ye-ZibaArchitecture and Urbanism (Memary Va Shahrsazi), 20, 1-15.

[17] Johnson, B. and Hill, K. (2002) Ecology and Design: Frameworks for Learning. Island Press, Washington DC.

[18] Bryant, M.M. (2006) Urban Landscape Conservation and the Role of Ecological Greenways at Local and Metropolitan Scales. Landscape and Urban Planning, 76, 23-44. http://dx.doi.org/10.1016/j.landurbplan.2004.09.029

[19] Aminzadeh, B. (2010) Evaluation of Beauty and Identity of Place. Hoviatshahr (The Identity of the City), 4, 75.

[20] Bolund, P. and Hunhammar, S. (1999) Ecosystem Services in Urban Areas. Ecological Economics, 29, $293-301$. 
http://dx.doi.org/10.1016/S0921-8009(99)00013-0

[21] Guattari, F. (2000) The Three Ecologies. The Athlone Press, London and New Brunswick, 35. (The Three Ecologies [1989], Trans. from the French by Ian Pindar and Paul Sutton.)

[22] Khakpoor, B. and Arfaii, J. (2012) Urban Future and the Future of Cities. Paper Presented at the First National Conference on Futures, Iran.

[23] Ziyari, C.A. (2001) Sustainable Development and Responsible Urban Planners in the Twenty-First Century. Faculty of Literature and Human Sciences, 160, 42.

[24] Wolman, A. (1965) The Metabolism of Cities. Scientific American, 213, 179-190. http://dx.doi.org/10.1038/scientificamerican0965-178

[25] Kennedy, C., Cuddihy, J. and Engel-Yan, J. (2007) The Changing Metabolism of Cities. Journal of Industrial Ecology, 11, 43-59. http://dx.doi.org/10.1162/jie.2007.1107

[26] Decker, E.H., Elliott, S., Smith, F.A., Blake, D.R. and Rowland, F.S. (2003) Energy and Material Flow through the Urban Ecosystem. Annual Review of Energy and the Environment, 25, 685-740. http://dx.doi.org/10.1146/annurev.energy.25.1.685

[27] Maclaren, V.W. (1996) Developing Indicators of Urban Sustainability. ICURR Press, Toronto.

[28] Baccini, P. and Bader, H.-P. (1996) Regionaler Stoffhaushalt. Spektrum Akademischer Verlag, Heidelberg.

[29] Cencic, O. and Rechberger, H. (2008) Material Flow Analysis with Software STAN. Environmental Informatics and Industrial Ecology, Lüneburg, 10-12 September 2008, 440-447.

[30] Oswald, F. and Baccini, P. (2003) Netzstadt. Springer, Berlin.

[31] Baccini, P. and Brunner, P.H. (1991) Metabolism of the Anthroposphere. Springer-Verlag.

[32] Quinn, D. and Fernandez, J. (2007) Urban Metabolism: Ecologically Sensitive Construction for a Sustainable New Orleans. School of Architecture and Planning MIT, Cambridge.

[33] Kennedy, C. (2007) Applying Industrial Ecology to Design a Sustainable Built Environment: The Toronto Port Lands Challenge. Engineering Sustainability Conference, Pittsburgh, 15-18 April 2007, 1-20.

[34] Codoban, N. and Kennedy, C.A. (2008) Metabolism of Neighborhoods. Journal of Urban Planning and Development, 134, 21-31. http://dx.doi.org/10.1061/(ASCE)0733-9488(2008)134:1(21) 